\title{
Assessment of Ecosystem Services for Planning of Green Infrastructure at the Regional Level
}

\author{
Maija Ušča \\ Institute of Agricultural Resources and \\ Economics \\ Riga, Latvia \\ maija.usca@arei.lv \\ Dāvis Valters Immurs \\ University of Latvia \\ Faculty of Geography and Earth \\ Sciences \\ Riga, Latvia \\ davis.immurs@1u.lv
}

\author{
Ivo Vinogradovs \\ University of Latvia \\ Faculty of Geography and Earth \\ Sciences \\ Riga, Latvia \\ ivo.vinogradovs@lu.lv \\ Anita Zarina \\ University of Latvia \\ Faculty of Geography and Earth \\ Sciences \\ Riga, Latvia \\ anita.zarina@lu.lv
}

\author{
Agnese Rekse \\ University of Latvia \\ Faculty of Geography and Earth \\ Sciences \\ Riga, Latvia \\ agnese.reke@lu.lv
}

\begin{abstract}
Ecosystem services (ES) are defined as the benefits that human beings derive from ecosystem functions. Assessment and mapping of these benefits are crucial for sustainable environmental planning and future natural capital. Green infrastructure (GI) is natural or semi-natural territories that provide wide range of ES. Human affected ecosystems tend to fail to provide certain sets of ES due to the trade-offs among those services, which could be mitigated through implementation of GI. Mapping of ES, as well as assessing the interactions among various ES and analysing their supply potential's cold/hot spots considerably enhances and substantiates the planning process of GI, particularly at the regional scale and for the territories with diverse landscape potential.
\end{abstract}

The aim of this paper is to discuss the assessment of ES supply potential and analyse its spatial distribution to reveal cold/hot spots of ecosystem capacity to provide wide range services and functions for GI. The study presents GIS based assessment of ES in a case study of Zemgale Planning Region. ES supply potential was assessed for 27 Corine land use classes (CLC2018) together with 10 regulatory, 12 provisioning and 6 cultural ES. An expertbased ranking approach using a two-dimensional ES matrix and a geospatial analysis was applied to determine total ES supply potential, spatial patterns and relations among multiple ES. Additional statistical analysis (Getis-Ord Gi*) was performed on spatial distribution of regulatory ES to disclose statistically significant capacity of ecosystems to function as GI in given surroundings. Preliminary results show uneven distribution of ES, trade-offs between regulatory and provisioning ES and landscape dependent spatial clustering of these trade-offs supported by result of Getis-Ord $\mathrm{Gi}^{*}$ analysis, thus laying a foundation for further planning of GI at the regional scale.

Keywords-ecosystem services, green infrastructure, Zemgale Planning Region.

\section{INTRODUCTION}

Ecosystem services (ES) are benefits that human obtain directly or indirectly from ecosystems [1]. In the Millennium Ecosystem Assessment all of the ES are classified into four categories: (1) supporting ES that are essential to provide other ecosystem services e.g., maintenance of biodiversity or habitat for species, biomass production, nutrient cycling and soil formation, (2) provisioning ES that provide people with direct benefits and can be identified as market value, e.g., hay for animal feeding, biomass for energy production, herbs for medical treatment, genetic resources, (3) regulating ES that are of paramount importance for the well-being of humanity, e.g., climate regulation, pollution reduction, erosion protection, (4) cultural EC that contribute to personal growth, raise knowledge, provide aesthetic enjoyment and recreational facilities, e.g., landscape and its aesthetic qualities and cultural heritage, providing the basis for recreation and tourism, as well as quality of life for living in that area [1], [2]. The concept of ES was introduced in 1980 , but only during the last years the inclusion of ES in policy and decision-making processes has been advocated for promoting sustainable development [3].

The idea of ES is closely linked to other definitions of natural components and their multiple functions. In the course of development ideas of ES have been followed by concepts of green infrastructure (GI) as well as naturebased solutions [4]. The European Commission defines GI as "a strategically planned network of natural and seminatural areas with other environmental features designed and managed to deliver a wide range of ecosystem services such as water purification, air quality, space for recreation and climate mitigation and adaptation" [5]. GI also plays a vital role in the conservation and enhancement of biodiversity and in tackling habitat fragmentation [6]. In this research we use quantitative assessment of ES to 
define areas at the regional level where GI (e.g. value of biodiversity, watershed protection etc.) is insufficient of lacking in order to support policy decisions about further planning process of GI. Thus, the aim of this paper is to discuss the assessment of ES supply potential and analyse its spatial distribution to reveal cold/hot spots of ecosystem capacity to provide wide range services and functions for GI.

\section{MATERIALS AND METHODS}

\section{A. Study area}

The study area is an administrative territory - Zemgale Planning Region (ZPR) that covers $10742 \mathrm{~km}^{2}$ and is situated in the central part of Latvia. It is comprised by diverse landscape regions: large tracts of intensive agricultural fields, mosaic type landscapes, as well as areas with large forest or wetland areas. The distribution of landscape types is related mainly to geo-ecological potential of the area, such as soil fertility, topography, drainage conditions. However, socio-economic processes, such as land abandonment and depopulation, have also affected landscape functions in the last decades, especially in the territories of marginal locations and of low agricultural potential. There are several natural features of historical value, such as, the River Daugava and the River Lielupe, which determine the largest settlement areas (towns of Jelgava, Bauska, Jēkabpils and others), while the nature protection areas are related to the distribution of natural wetlands (mires and bogs), but also - river valleys.

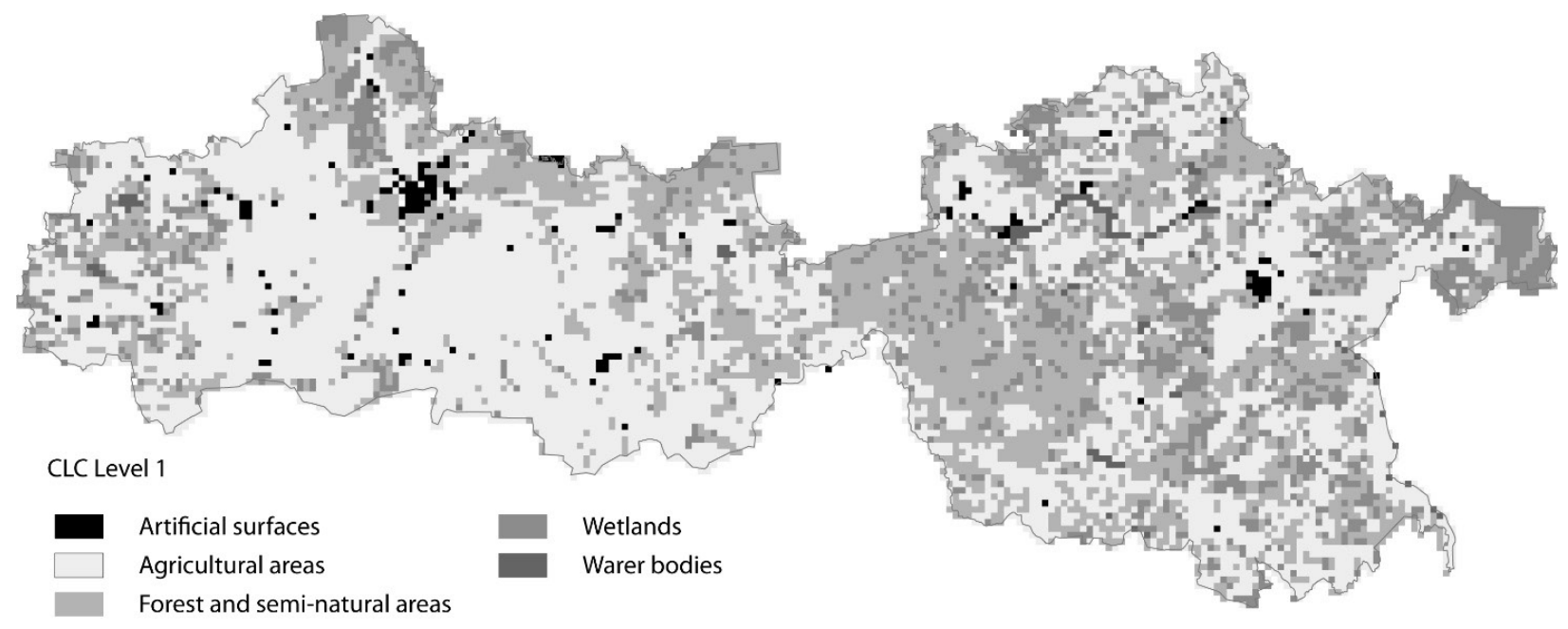

Fig. 1. Land use in ZPR according to (CLC2018)

According to the level 1 of Corine land use classes (CLC2018), the territory of ZPR is composed by $1.75 \%$ of artificial surface, $49.31 \%$ agricultural area, $45.11 \%$ forest and semi-natural area, 2.63\% wetlands and $1.21 \%$ of water bodies (Fig. 1).

\section{B. Methods}

This study used the CICES v.4.3, the most widely used classification of ecosystem services, where support services are not considered separately, as they are assumed to be a prerequisite for other service categories. The ES matrix method, developed by Burkhad et al. [8] [10], was used to assess the ES. It is a semi-quantitative, adaptive and efficient GIS technique to assess the potential of ecosystems to provide certain services based on the type of Land Cover / Land Use (LCLU). This method uses the CORINE LCLU type class as a basis for expert judgment on the potential of this class to provide a separate service. A list of ES that included regulatory ES and supply ES (Table 1) was adapted from previous studies [1], [11] - [13] and adjusted to the specifics of the ZPR. The expert assessment was based on the ES assessment study [14] in the territory of Lithuania. The ES potential was mapped using a $1 \times 1 \mathrm{~km}$ grid to provide further data analysis capabilities, especially hot and cold spots, ES clusters, and ES interactions. The grid used is fully in line with the grid of data collection of the Central Statistical Bureau of Latvia, thus it contains the potential to link the analysis of the spatial distribution of ES supply potential to the socio-economic indicators.

The results of the identification of the ES supply potential were used to identify ES clusters - ES bundles within which the ES interacts. The analysis was performed in SPSS software using the Principal Component (PCA) statistical procedure, which is able to divide the dataset into components, thus highlighting potential ES bundles. Sums of ES supply potentials of the ES Group (Regulatory, Production, Cultural) were used as a basis for spatial-statistical analysis in ArcGIS software using the Hot Spot Analysis (Getisi-Ord Gi *) procedure, thus separating statistically significant cold and hot spots of the ES group's supply potential. 
TABLE I. ECOSYSTEM SERVICES USED IN THE STUDY AND INDICATORS DESCRIBING THEM (CICES)

\begin{tabular}{|c|c|}
\hline Ecosystem services & Potential indicators \\
\hline \multicolumn{2}{|c|}{ Regulating EC } \\
\hline $\begin{array}{l}\text { Global climate regula- } \\
\text { tion (GCR) }\end{array}$ & $\begin{array}{l}\text { Emitted-associated } \mathrm{CO}^{2} \text {, meth- } \\
\text { ane, water vapours, etc.. }\end{array}$ \\
\hline $\begin{array}{l}\text { Local climate regula- } \\
\text { tion }(\mathrm{LCR})\end{array}$ & $\begin{array}{l}\text { Temperature (amplitudes), albe- } \\
\text { do, precipitation, evaporation. }\end{array}$ \\
\hline $\begin{array}{c}\text { Air quality regulation } \\
(\mathrm{AQR})\end{array}$ & $\begin{array}{l}\text { Leaf area index, amplitude of } \\
\text { pollution indicators. }\end{array}$ \\
\hline $\begin{array}{l}\text { Water flow regulation } \\
\text { (WFR) }\end{array}$ & Amount of water on hold \\
\hline $\begin{array}{l}\text { Water purification } \\
\text { (WP) }\end{array}$ & Water quality and quantity \\
\hline $\begin{array}{l}\text { Nutrient regulation } \\
(\mathrm{NR})\end{array}$ & $\begin{array}{c}\text { Balance of } \mathrm{N}, \mathrm{P} \text { and other sub- } \\
\text { stances }\end{array}$ \\
\hline $\begin{array}{l}\text { Erosion regulation } \\
\text { (ER) }\end{array}$ & $\begin{array}{l}\text { Quantity of particles on hold, } \\
\text { ground coverage }\end{array}$ \\
\hline $\begin{array}{l}\text { Natural hazard regula- } \\
\text { tion (NHR) }\end{array}$ & $\begin{array}{l}\text { Quantity of floods, fires, frequen- } \\
\text { cy pf them }\end{array}$ \\
\hline Pollination (POL) & Number of pollinators \\
\hline $\begin{array}{l}\text { Pest and disease con- } \\
\text { trol (PDC) }\end{array}$ & $\begin{array}{c}\text { Diversity of landscape and } \\
\text { species, spreading of diseases and } \\
\text { pest sites }\end{array}$ \\
\hline \multicolumn{2}{|c|}{ Provisioning EC } \\
\hline Crops (CRO) & Harvest, t/ha \\
\hline $\begin{array}{l}\text { Biomass for energy } \\
\text { (BFE) }\end{array}$ & Biomass $\mathrm{t} / \mathrm{ha}, \mathrm{kJ} / \mathrm{ha}$ \\
\hline Fodder (FOD) & Fodder $\mathrm{t} / \mathrm{ha}$ \\
\hline Livestock (LST) & Animal units /ha \\
\hline Fibber (FBR) & Fibber t/ha \\
\hline Timber (TBR) & Timber $\mathrm{m}^{3} / \mathrm{ha}$ \\
\hline Wood fuel (WDF) & Wood $\mathrm{m}^{3} / \mathrm{ha}$ \\
\hline Fish $(\mathrm{FSH})$ & $\mathrm{t} / \mathrm{ha}$ \\
\hline Aqua culture (AQC) & $\mathrm{t} / \mathrm{ha}$ \\
\hline $\begin{array}{l}\text { Wild foods and } \\
\text { resources (WDR) }\end{array}$ & $\mathrm{t} / \mathrm{ha}$ \\
\hline $\begin{array}{l}\text { Biochemicals and } \\
\text { medicine (BCM) }\end{array}$ & $\mathrm{t} / \mathrm{ha}$ \\
\hline Fresh water (FRW) & $\mathrm{m}^{3} / \mathrm{ha}$ \\
\hline \multicolumn{2}{|c|}{ Cultural EC } \\
\hline $\begin{array}{l}\text { Recreation and tour- } \\
\text { ism (RCT) }\end{array}$ & $\begin{array}{l}\text { Relative fitness of the ecosystem } \\
\text { for recreation and tourism }\end{array}$ \\
\hline $\begin{array}{l}\text { Landscape aesthetics } \\
\text { and inspiration (LAI) }\end{array}$ & $\begin{array}{l}\text { Relative suitability of the ecosys- } \\
\text { tem for enjoyment and inspiration }\end{array}$ \\
\hline $\begin{array}{l}\text { Knowledge systems } \\
\text { (KNS) }\end{array}$ & $\begin{array}{l}\text { Relative relevance of the eco- } \\
\text { system to the maintenance of } \\
\text { knowledge systems }\end{array}$ \\
\hline $\begin{array}{l}\text { Religious and spiritual } \\
\text { experience (RSE) }\end{array}$ & $\begin{array}{c}\text { The relative capacity of the eco- } \\
\text { system to provide religious and } \\
\text { mental experience }\end{array}$ \\
\hline $\begin{array}{l}\text { Cultural heritage and } \\
\text { cultural diversity } \\
\text { (CHD) }\end{array}$ & $\begin{array}{l}\text { Relative relevance of the eco- } \\
\text { system to the maintenance of } \\
\text { cultural heritage and diversity }\end{array}$ \\
\hline $\begin{array}{l}\text { Natural heritage and } \\
\text { natural diversity } \\
\text { (NHD) }\end{array}$ & $\begin{array}{l}\text { Relative relevance of the eco- } \\
\text { system to the maintenance of } \\
\text { cultural heritage and diversity }\end{array}$ \\
\hline
\end{tabular}

\section{RESULTS AND DISCUSSION}

Assessment of ecosystem services was based on CORINE CLC type classes. The assessment was carried out on a relative scale of 1-5, indicating the potential of the given ES collateral (1-very low, 2-low, 3-average, 4-high, 5-very high). 0 is given in a situation where the service is not provided (Table 2).

\begin{tabular}{|c|c|c|c|c|}
\hline CLC type (Corine) & 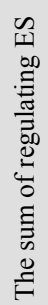 & 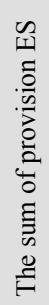 & 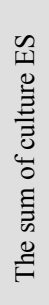 & 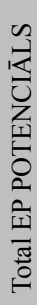 \\
\hline Discontinuous urban fabric & 3 & 2 & 17 & 22 \\
\hline Industrial or commercial units & 0 & 1 & 4 & 5 \\
\hline Road and rail networks & 0 & 0 & 10 & 10 \\
\hline Airports & 0 & 0 & 0 & 0 \\
\hline Mineral extraction sites & 0 & 8 & 5 & 13 \\
\hline Dump sites & 0 & 3 & 1 & 4 \\
\hline Sport and leisure facilities & 14 & 0 & 9 & 23 \\
\hline Non-irrigated arable land & 11 & 24 & 13 & 48 \\
\hline Fruit trees and berries & 22 & 16 & 17 & 55 \\
\hline Pastures & 20 & 19 & 16 & 55 \\
\hline Complex cultivation patterns & 15 & 18 & 11 & 44 \\
\hline Agriculture \& natural vegetation & 25 & 21 & 19 & 65 \\
\hline Broad-leaved forest & 49 & 22 & 20 & 91 \\
\hline Coniferous forest & 46 & 22 & 22 & 90 \\
\hline Mixed forest & 47 & 22 & 21 & 90 \\
\hline Natural grassland & 28 & 14 & 19 & 61 \\
\hline Transitional woodland shrub & 19 & 9 & 11 & 39 \\
\hline Inland marshes & 29 & 9 & 13 & 51 \\
\hline Peatbogs & 35 & 7 & 22 & 64 \\
\hline Water courses & 21 & 17 & 22 & 60 \\
\hline Water bodies & 24 & 20 & 22 & 66 \\
\hline
\end{tabular}

The results obtained were analysed in the SPSS software, using the statistical procedure of the principle components analysis (PCA) and potential ES bundles were highlighted. Using the Hot Spot Analysis (Getisi-Ord $\mathrm{Gi}^{*}$ ) procedure in the ArcGIS software 1 x $1 \mathrm{~km}$ network grid, the cold and hot spots of statistically significant ES bundles potential were distributed. As the main trade-offs of ES in the context of green infrastructure are linked to benefits obtained from regulation of ecosystems, further in the research we will probe into one class of ES regulating services. The map of regulating ES reveals the spatial distribution of hot and cold spots of the services (Fig. 2). The hotter the spot (red), the amount of service is higher, the colder the spot (blue), more statistically significant the lack of specific ES in the territory. Regional scale analysis of areas covered by forests (Fig. 1) reveal to be the hotspots of regulating ES (Fig. 2), while the areas intensively used for agriculture purposes as well as the territories with higher density of inhabitants reveal to be cold spots, i.e., spatial clustering of specific ES depends on the dominating land use. 


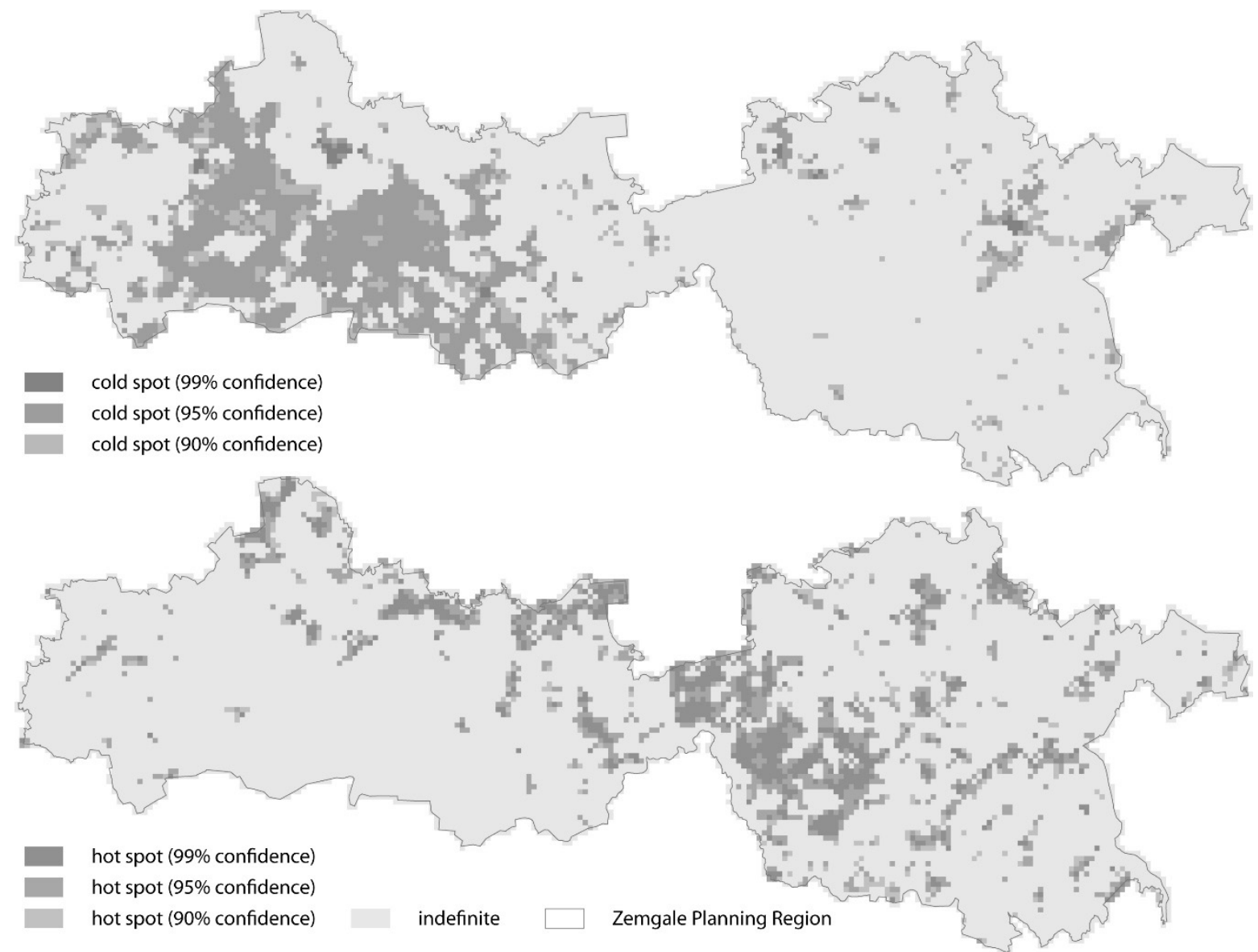

Fig. 2. The hot/cold spots of regulating ecosystem services supply potential in ZPR

The map of regulating ES reveals the spatial distribution of hot and cold spots of the services (Fig. 2). The hotter the spot (red), the amount of service is higher, the colder the spot (blue), more statistically significant the lack of specific ES in the territory. Regional scale analysis of areas covered by forests (Fig. 1) reveal to be the hotspots of regulating ES (Fig. 2), while the areas intensively used for agriculture purposes as well as the territories with higher density of inhabitants reveal to be cold spots, i.e., spatial clustering of specific ES depends on the dominating land use.

The central part of ZPR, where the landscape of agricultural lands with a dense network of rivers prevail, plays a crucial role in the warranty of provisional ES, but it lacks regulating ones. Thus, intensive farming practices result in contamination of surrounding water bodies and decline of biodiversity. It means that various components of green infrastructure dealing with the reduction of agricultural runoffs and pollution, e.g. buffer-zones between agricultural lands and water bodies that would minimize the negative impacts of agricultural pollution, should be planned and implemented in the agricultural landscape. At the same time trade-offs between provision ES and regulating ES should be analysed when planning green infrastructure.

More densely populated territories (towns and villages), disclose the lack of ES potential in both (regulating and provisioning) classes. In these areas cold spots of regulating as well as provisional ES prevail (Fig. 2). This is related to the continuous urban fabric, which significantly reduces the capacity of regulating and provisioning ES [14]. Therefore, when referring to green infrastructure, these territories should be taken into account primarily. Components of green infrastructure, e.g., buffer zones, green corridors and pathways, should be planned and implemented there.

In the context of the evaluation of the planning of GI, the main role is played by existing deployment and availability of regulatory ES. Previous researches have shown that management that attempts to maximize a particular ES often results in substantial declines in the provision of other ES [15]. Therefore, when assessing potential development areas of GI, deployment of provisioning and cultural ES should also be taken into account. This makes it possible to assess the relationship between all groups of ES and to find the best trade-offs between them.

\section{CONCLUSIONS}

The approach used in the research shows a capability to cover geographic areas at a regional scale in order to map ES. The results disclose the potential of ES assessment and mutual matching of them in order to find trade-offs between classes of ES in order to prioritize territories for GI development as well as to support and substantiate GI planning at the regional and national level. The method can support the decision-making processes in the field of regional planning, nature protection and GI development as a whole. Mapping of ES, as well as assessing the interactions among various ES and analysing their supply 
potential's cold/hot spots, considerably enhances and substantiates the planning process of GI, particularly at the regional scale and for the territories with diverse landscape potential.

This research is the first attempt to use the assessment of ES in GI planning at regional level in Latvia. The results reveal uneven distribution of ES thus showing the necessity to estimate trade-offs between regulatory and provisioning ES as well as landscape dependent spatial clustering of these trade-offs. Thus, the study is laying s a foundation for further planning of GI at the regional scale.

\section{REFERENCES}

[1] Millennium Ecosystem Assessment. Ecosystems and Human Well-being, 2005.

[2] M. Villoslada, I. Vinogradovs, A. Ruskule, K. Veidemane, O. Nikodemus, R. Kasparinskis, K. Sepp and J.Gulbinas, "A multitiered approach for grassland ecosystem services mapping and assessment: The Viva Grass tool,” One Ecosystem 3: e25380, 2018.. Available: https://doi.org/10.3897/oneeco.3.e25380

[3] A.D. Guerry, S. Polasky, J. Lubchenco, R. Chaplin-Kramer, G. C. Daily, R. Griffin, M. Ruckelshaus, I.J. Bateman, A. Duraiappah, T. Elmqvist, M. W. Feldman, C. Folke, J. Hoekstra, P.M. Kareiva, B.L. Keeler, S. Li, E. McKenzie, Z. Ouyang, B. Reyers, T. H. Ricketts, J. Rockström, H. Tallis, and B. Vira, "Natural capital and ecosystem services informing decisions: From promise to practice", Proceedings of the National Academy of Sciences of the United States of America, 112 (24), p. 7348-7355, June 16, 2015. Available: https://doi.org/10.1073/pnas.1503751112

[4] F. J.Escobedoa, V. Giannico, C.Y. Jim, G. Sanesi, R. Lafortezza, "Urban forests, ecosystem services, green infrastructure and nature-based solutions: Nexus or evolving metaphors?," Urban Forestry \& Urban Greening, vol. 37, p. 3-12, January 2019. [Online]. Available: https://doi.org/10.1016/j.ufug.2018.02.011

[5] European Commission Green Infrastructure (GI) — Enhancing Europe's Natural Capital. Communication from the commission to the European parliament, the council, the European economic and social committee and the committee of the regions, 2013. Available: https://eur-lex.europa.eu/legal-content/EN/TXT/?uri=CELEX:52013DC0249
[6] C.V. Mejía, L. Shirotova, I F. Marques de Almeida, "Green Infrastructure and German Landscape Planning: A Comparison of Approaches," Urbani izziv, vol. 26, p. 25-37, 2015. Available: http://urbani-izziv.uirs.si/Portals/uizziv/papers/urbani-izziv-en2015-26-supplement-002.pdf

[7] Statistics of Latvia, Central Statistical Bureau of Latvia, 2017. [Accessed November 20, 2018], Available: https://www.csb.gov. $\underline{\mathrm{lv} / \mathrm{lv} / \mathrm{statistika} / \mathrm{db}}$

[8] B. Burkhard, F. Kroll, F. Müller, W. Windhorst, "Landscapes' capacities to provide ecosystem services - a concept for land-cover based assessments," Landscape Online 15, p. 2-22., 2009. Available: : https://doi.org/10.3097/LO.200915

[9] B. Burkhard, F. Kroll, S. Nedkov, F. Müller, "Mapping ecosystem service supply, demand and budgets," Ecological Indicators, vol. 21, p. 17-29, October 2012. Available: https://doi.org/10.1016/j. ecolind.2011.06.019

[10] B. Burkhard, M. Kandziora, Y. Hou, F. Müller, "Ecosystem service potentials, flows and demands - concepts for spatial localisation, indication and quantification," Landsc Online, vol. 34, p.132, 2014. Available: https://doi.org/10.3097/LO.201434

[11] R. Costanza, R. d'Arge, R. de Groot, S. Farberk, M. Grasso, B. Hannon, K. Limburg, S. Naeem, O. Rv, J. Paruelo, R. G. Raskin, P. Sutton and M.van den Belt. "The value of the world's ecosystem services and natural capital," Nature 387, p.253-260, 1997. Available: https://doi.org/10.1038/387253a0

[12] R.S. de Groot, M.A. Wilson, R.M.J. Boumans, “A typology for the classification, description and valuation of ecosystem functions, goods and services," Ecological Economics, vol. 41, no. 3, p. 393-408, June 2002. Available: https://doi.org/10.1016/S0921$\underline{8009(02) 00089-7}$

[13] The Economics of Ecosystems and Biodiversity. The economics of ecosystems and biodiversity: mainstreaming the economics of nature: a synthesis of the approach, conclusions and recommendations of TEEB, Malta, 2010, UNEP. Available: http://doc. teebweb.org/wp-content/uploads/Study $\% 20$ and $\% 20$ Reports $/$ Reports/Synthesis $\% 20$ report/TEEB $\% 20$ Synthesis $\% 20$ Report $\% 20$ 2010.pdf

[14] D. Depellegrin, P. Pereira, I. Misiune and L. Egarter-Vigl "Mapping ecosystem services potential in Lithuania", International Journal of Sustainable Development \& World Ecology vol. 23, no.5, p. 441-455, 2016. Available: https://doi.org/10.1080/13504 $\underline{509.2016 .1146176}$

[15] E.M. Bennett, G.D. Peterson, L. Gordon, "Understanding relationships among multiple ecosystem services", Ecology Letters 12, p. 1394-1404, 2009. Available: https://doi.org/10.1111/ j.1461-0248.2009.01387.x 